\title{
Characterization of the Outfall Area of a Multi-Stage-Flash Desalination Plant in Bahrain
}

\author{
Waleed K. Al-Zubari, Alaa A. El-Sadek, Mohamed J. Khadim \\ Water Resources Management Program, College of Graduate Studies, Arabian Gulf University, Manama, Kingdom of Bahrain \\ Email: waleed@agu.edu.bh; alaasa@agu.edu.bh
}

How to cite this paper: Al-Zubari, W.K., El-Sadek, A.A. and Khadim, M.J. (2018) Characterization of the Outfall Area of a Multi-Stage-Flash Desalination Plant in Bahrain. Journal of Water Resource and Protection, 10, 287-303.

https://doi.org/10.4236/jwarp.2018.103017

Received: February 22, 2018

Accepted: March 16, 2018

Published: March 19, 2018

Copyright $\odot 2018$ by authors and Scientific Research Publishing Inc. This work is licensed under the Creative Commons Attribution International License (CC BY 4.0).

http://creativecommons.org/licenses/by/4.0/

\section{Abstract}

In Bahrain, like the other Gulf Cooperation Council (GCC) countries, desalination is inevitable to meet the escalating municipal water demands. However, desalination is associated with many environmental effects, which need to be minimized to their lowest possible limits. One of the major environmental concerns of desalination in the Arabian Gulf region is the local and regional effects of the outfall areas on the marine environment. In this study, the outfall area of a government-owned MSF desalination plant is characterized in terms of temperature and salinity. The spatial extent of the plume of the desalination plant's effluent is mapped by a field survey conducted during the winter season around the plant's outfall area at $25 \mathrm{~cm}$ and $1 \mathrm{~m}$ below the water surface and at low and high tide. The results of the characterization indicated that the temperature of the brine discharged to the outfall was $37^{\circ} \mathrm{C}$, higher than the ambient seawater temperature by $16.5^{\circ} \mathrm{C}$ at high tide and $17.5^{\circ} \mathrm{C}$ at low tide, and that the extent of the mixing zone area was found at about $260 \mathrm{~m}$ and $1 \mathrm{~km}$ from the outfall point at high tide and low tide, respectively. The results also showed that brine thermal discharge is not in compliance with the standard limits $\left(<3^{\circ} \mathrm{C}\right.$ from ambient within $100 \mathrm{~m}$ of shoreline) both at high and low tides with differences reaching more than $10^{\circ} \mathrm{C}$. In terms of salinity, the brine discharged salinity was 56.2 parts per trillion (ppt) compared to an ambient seawater salinity of $43.2 \mathrm{ppt}$. The maximum salinity measured near the outfall point was $56 \mathrm{ppt}$ at low tide and $51 \mathrm{ppt}$ at high tide, both at $1 \mathrm{~m}$ below the surface water column. It is found that the current design structure consisting of two jetties to isolate the desalination plant outfall area from its surroundings is not environmentally sound, as the current surface/inter-tidal outfall location is susceptible to significant increases in salinity and temperature around the outfall area due to the limited flushing it experiences. Therefore, the current design of the outfall area needs to be reviewed to ensure meeting brine discharge regulations and mitigate its impact on the surrounding marine area. The spatial extent of the brine plume can be 
minimized by building a discharge area further offshore at a sub-tidal location where turbulent flow exists to minimize the spatial extent and intensity of the brine plume. It is recommended that this characterization be extended to all desalination plants in Bahrain, and a regular monitoring program, which should also include selected biological communities and organisms of ecological relevance, be established around the desalination plants outfall areas.

\section{Keywords}

Desalination, Brine, Salinity, Temperature, GCC Countries, Bahrain

\section{Introduction}

Like the rest of the GCC countries, Bahrain has extremely poor endowment of water resources. It has one of the lowest per capita renewable freshwater resources in the world that continue to decline rapidly due to escalating population growth (Figure 1). Overall per capita renewable freshwater availability in Bahrain has been rapidly declining from about 500 cubic meters per year $\left(\mathrm{m}^{3} / \mathrm{yr}\right)$ in 1970 to about $80 \mathrm{~m}^{3} / \mathrm{yr}$ in 2010 , considerably below the acute water poverty line of $500 \mathrm{~m}^{3} / \mathrm{yr}$, where water becomes a major constraint for development impacting the standard of living, health and the environment [1]. However, despite the rapid increase in water demands and the limitation of its conventional freshwater resources, Bahrain has done well in providing drinking water for its rapidly expanding population by resorting to desalination. Per capita desalination capacity share has been increasing from about $11 \mathrm{~m}^{3}$ in 1980 to about 170 in 2010. This share continues to increase with time. In 2012 per capita desalination capacity share in Bahrain was about $180 \mathrm{~m}^{3}$.

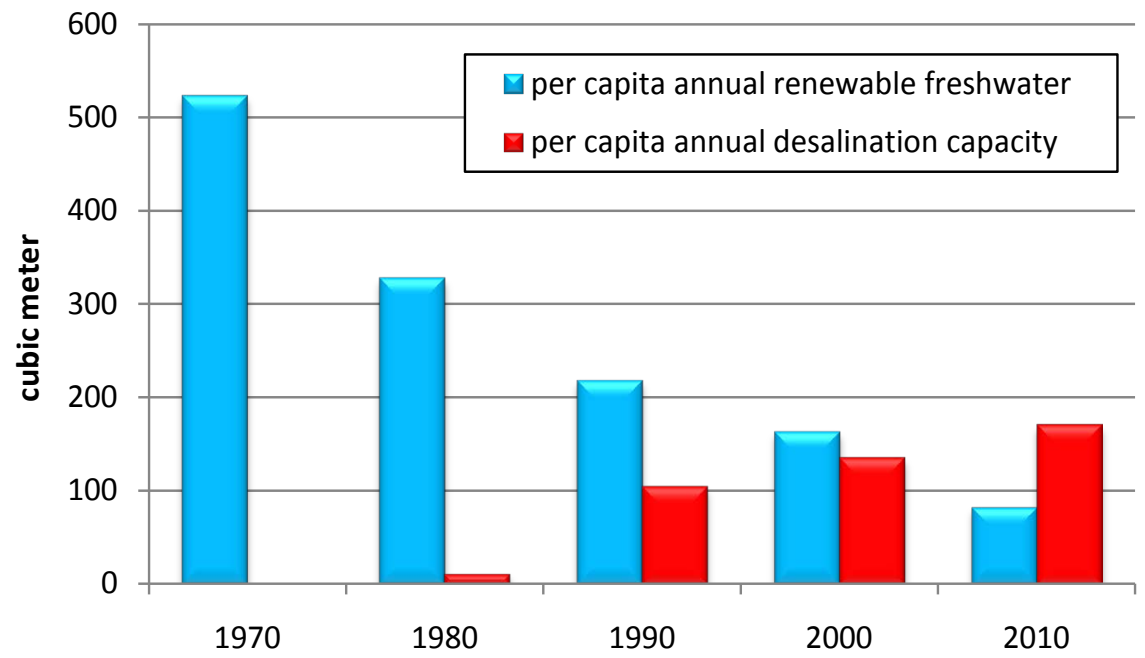

Figure 1. Trends of availability of annual per capita renewable freshwater and desalination capacity in Bahrain, 1970-2010. 
Desalination technology was introduced in Bahrain in 1975 and has developed very rapidly to counteract the shortage and quality deterioration in groundwater resources and to meet the qualitative requirements for drinking water standards. Figure 2 illustrates the trend in desalination water production to meet municipal water demands in the country. At present, municipal water supply in Bahrain relies mainly on desalinated water, which is used either directly or blended with groundwater, which has significantly positive implication on the quality of the supplied water. The quality of the supplied municipal water meets the Bahrain/GCC high drinking water quality standards in terms of salinity $(<500$ $\mathrm{mg} / \mathrm{L}$ ) and beyond.

In Bahrain there are five major operating desalination plants, all of which located at the eastern coast of the country (Figure 3). The details of these desalination plants are indicated in Table 1 . In 2014, the total desalination capacity was about $870 \mathrm{~m}^{3} / \mathrm{d}\left(315 \mathrm{Mm}^{3} / \mathrm{yr}\right)$. Like the GCC countries, the current trend in desalination expansion in Bahrain is expected to continue in the future [2].

The primary desalination process used in Bahrain is the thermal process (64\%), namely the Multi-Stage-Flash (MSF) distillation and the Multiple Effect Distillation (MED) technologies. The MSF technology is an established technology and is combined with co-generation of electricity which greatly improves the economics of desalination. It also exhibits significant economies of scale which are critical for large scale production. In addition, MSF plants have a useful life of about 25 years that can be nearly doubled through proper plant maintenance and refurbishment. The MED combined with thermal vapor compression, is more energy-efficient even for smaller desalination plants than MSF, and has been increasing in Bahrain as well as in the Arabian Gulf region in the past few years. On the other hand, Reverse Osmosis (RO) technology, both seawater and brackish water, have been adopted recently for relatively large plant (i.e., Al-Dur Seawater RO).



Figure 2. Trends in municipal water supply and its sources in Bahrain, 1980-2011 (data source: Electricity and Water Authority). 


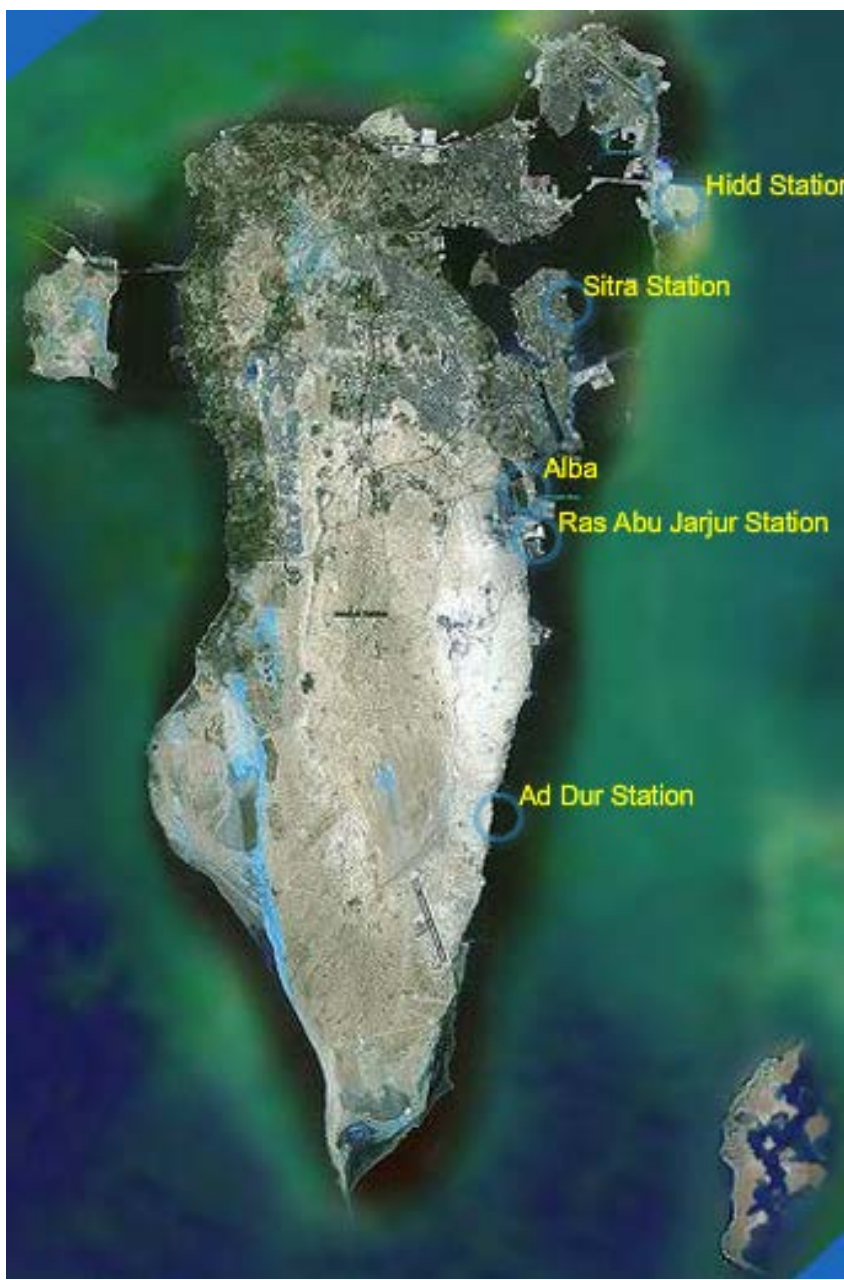

Figure 3. Desalination plants locations in Bahrain.

Table 1. Daily production capacity of desalination plants in Bahrain.

\begin{tabular}{|c|c|c|c|c|c|c|c|c|}
\hline No. & Plant & $\begin{array}{l}\text { Commissioning } \\
\text { Date }\end{array}$ & Technology Used & No. of Units & $\begin{array}{l}\text { Capacity } \\
1000 \mathrm{~m}^{3} / \mathrm{d}\end{array}$ & $\begin{array}{c}\text { Feed } \\
\text { Water }\end{array}$ & $\begin{array}{l}\text { Ownership/ } \\
\text { Management }\end{array}$ & Ratio of Brine \\
\hline 1 & $\begin{array}{c}\text { Sitra } \\
\text { (SPWS) }\end{array}$ & 1975 & $\begin{array}{l}\text { Multistage-Flash } \\
\text { (MSF) }\end{array}$ & 6 & 113.6 & Seawater & Governmental & $11 \mathrm{X}$ produced \\
\hline 2 & $\begin{array}{c}\text { Ras } \\
\text { AbuJarjur } \\
\text { (RAJ) }\end{array}$ & 1984 & Reverse Osmosis & 10 & 77.3 & $\begin{array}{c}\text { Brackish } \\
\text { Groundwater }\end{array}$ & Governmental & $1.4 \mathrm{X}$ produced \\
\hline 3 & $\begin{array}{l}\text { AdDur } \\
\text { (ADUR) }\end{array}$ & 1990 & Reverse Osmosis & 8 & 18.2 & Seawater & Governmental & $2.5 \mathrm{X}$ produced \\
\hline 4 & Hidd & 1999 & $\begin{array}{c}\text { Multistage-Flash } \\
\text { (MSF) and } \\
\text { Multi-Effect } \\
\text { Distillation (MED) }\end{array}$ & $\begin{array}{c}14 \\
\text { (4 MSF and } 10 \mathrm{MED})\end{array}$ & 409.1 & Seawater & $\begin{array}{c}\text { Privatized } \\
\text { (entire production } \\
\text { purchased) }\end{array}$ & $\begin{array}{l}2 \mathrm{X} \text { produced } \\
2.5 \mathrm{X} \text { produced }\end{array}$ \\
\hline 5 & Alba & 2002 & $\begin{array}{c}\text { Multi-Effect } \\
\text { Distillation (MED) }\end{array}$ & 4 & 31.8 & Seawater & $\begin{array}{c}\text { Private } \\
\text { (production purchased) }\end{array}$ & Not available \\
\hline 6 & $\begin{array}{l}\text { Al-DUR } \\
\text { RO }\end{array}$ & 2012 & Reverse Osmosis & - & 220.0 & Seawater & $\begin{array}{c}\text { Private } \\
\text { (production purchased) }\end{array}$ & $2.5 \mathrm{X}$ produced \\
\hline \multicolumn{5}{|c|}{ Total Desalination capacity } & 870 & & & \\
\hline
\end{tabular}

Source: Electricity and Water Authority Data. Note: Al Dur SWRO, owned by EWA, is no more existing as a production facility; currently it is mothballed until a time that EWA may refurbish, upgrade it, or place it by a new plant (plant \#6). 
However, while Bahrain has been able to meet the rising municipal water demands by the expansion of desalination plants production, this has been associated with enormous costs manifested by Al-Zubari (2014) [3]: 1) the required energy (oil and gas) for desalinated water production (including its opportunity cost and in-situ value);2) financial and energy/electricity cost of every stage in the operation of the water cycle system (i.e., production, transmission, and distribution); and 3) environmental costs in terms of thermal brine and other waste products discharge by desalination plants and their impacts on the surrounding coastal and marine environment, as well as air pollution by burned fossil fuel and their impacts on human health and the environment.

Depending on the physical and ecological characteristics of the receiving waters, these substances can have a harmful impact on the local environment. Especially vulnerable are areas such as mangroves, salt marshes, coral reefs, or generally, low energy intertidal areas; enclosed seas, such as the Arabian Gulf, have limited water exchange capacities and are generally shallow and less energetic, thus more sensitive to effluent discharges [4]. Discharge of waste products chemicals (i.e., biocides, chlorination, and de-scaling chemicals) can lead to chronic toxicity and small-scale alterations to community structure in marine environments, particularly for corals [5]. Moreover, as desalination effluents has high salinity and denser than seawater, they sink to the seabed and slowly circulates causing harm to sea grasses and other ecosystems on which a large range of aquatic life depend [6] [7]. Changes to salinity can play a significant role in the growth and size of aquatic life and the marine species disturbance [8].

In light of the current population growth and municipal water consumption trends, expansion in desalination is inevitable to meet the escalating municipal water requirements in Bahrain. Therefore, management efforts have to be made on both the supply and demand sides, to reduce its associated costs to the minimum levels possible. This can be achieved by improving water efficiency (use, supply, recycle, reuse) in the municipal water supply sector to reduce water requirements, and thus reducing desalination production and its associated financial, economic and environmental costs.

Yet, desalination externalities will continue to impact the marine environment and ecology, and will need to be mitigated to the minimum possible levels by technical and technological means. For new desalination plants, basic knowledge of the resulting concentration distributions allows for an impact assessment and design optimization. The concentration distribution depends on the sitting of the outfall, the amount of mixing and the transport capacities of the prevailing currents [9].

On the other hand, for an existing desalination plant, a typical environmental impact assessment and mitigation procedures would involve outfall site characterization and modeling approach to improve the design of the discharge such that effluent impacts are minimized. Such approach would require the followings steps: the impact of a given desalination plant on the surrounding marine 
environment is characterized in the vicinity of the brine discharge area; then, the results of the characterization stage are used to calibrate and develop a hydrodynamic simulation model (e.g., CORMIX) for the desalination plant and its surrounding marine environment; once the simulation model is calibrated to satisfactorily represent the existing system of the desalination plant and its surrounding marine area, it is used to investigate the effectiveness of various proposed mitigation options.

Mitigation options can be made either within the desalination plant itself (e.g., to dilute brine with power plant cooling waters [10], dilute brine with seawater prior to discharge [11] [12], and development of effective anti-scalants with no biological effects [13] [14], or at the outfall area, such as submerged discharge via pipeline and nozzle or diffuser further offshore [15] [16] [17] [18].

In this research, the outfall area of an MSF desalination plant in Bahrain is characterized in terms of temperature and salinity, and the horizontal and vertical extent of the plume of the desalination plant's effluent is investigated. Such basic knowledge of the spatial distribution of the salinity and temperature of the effluent is necessary for an environmental impact assessment, hydrodynamic modeling of the outfall area and for evaluating the effectiveness of any proposed mitigation options.

\section{Materials and Methods}

\subsection{Location and Description of the Desalination Plant}

The study was conducted on the outfall area of Sitra Power and Water Station (SPWS). SPWS's Phase I was commissioned in 1975 and was designed to meet the growing demand for electricity and drinking water in Bahrain. Consisting of four sets of boilers, steam turbo generators and two Multi-stage flash (MSF) seawater desalination units, the facility has a design production capacity of 100 Mega Watts (MW) of electricity and 22,725 $\mathrm{m}^{3} /$ day (5MGPD) of distilled water. In 1984, phase II of SPWS was commissioned and consisted of a $25 \mathrm{MW}$ gas Turbine with a waste heat recovery boiler, an auxiliary boiler, and a 22,725 $\mathrm{m}^{3} /$ day (5MGPD) capacity MSF unit. Phase II, or unit 5 is a self-contained plant with separate support infrastructure including: gas supply, seawater Intake, outfall culvert, and other Auxiliary System. In order to meet further growth in demand for electricity and water, Phase III was commissioned in 1984/85. Phase III consisted of three identical MSF units, each with an installed capacity of $22,725 \mathrm{~m}^{3} /$ day (5MGPD) when operated at $90^{\circ} \mathrm{C}$ Top Brine Temperature (TBT), but capable of producing $30,906 \mathrm{~m}^{3}$ /day (6.8MGPD) When operated at $110^{\circ} \mathrm{C}$ (TBT).

SPWS has two seawater intakes and four outfall culverts. A flow diagram of the intake and outfall is shown in Figure 4. The outfall area is being constrained by two jetties. These Jetties, shown in Figure 5, were constructed to minimize the spread of brine plumes and thus minimize areas of ecological impacts, and in the case of the north jetty to limit the intrusion of brines into seawater intake areas [19]. 

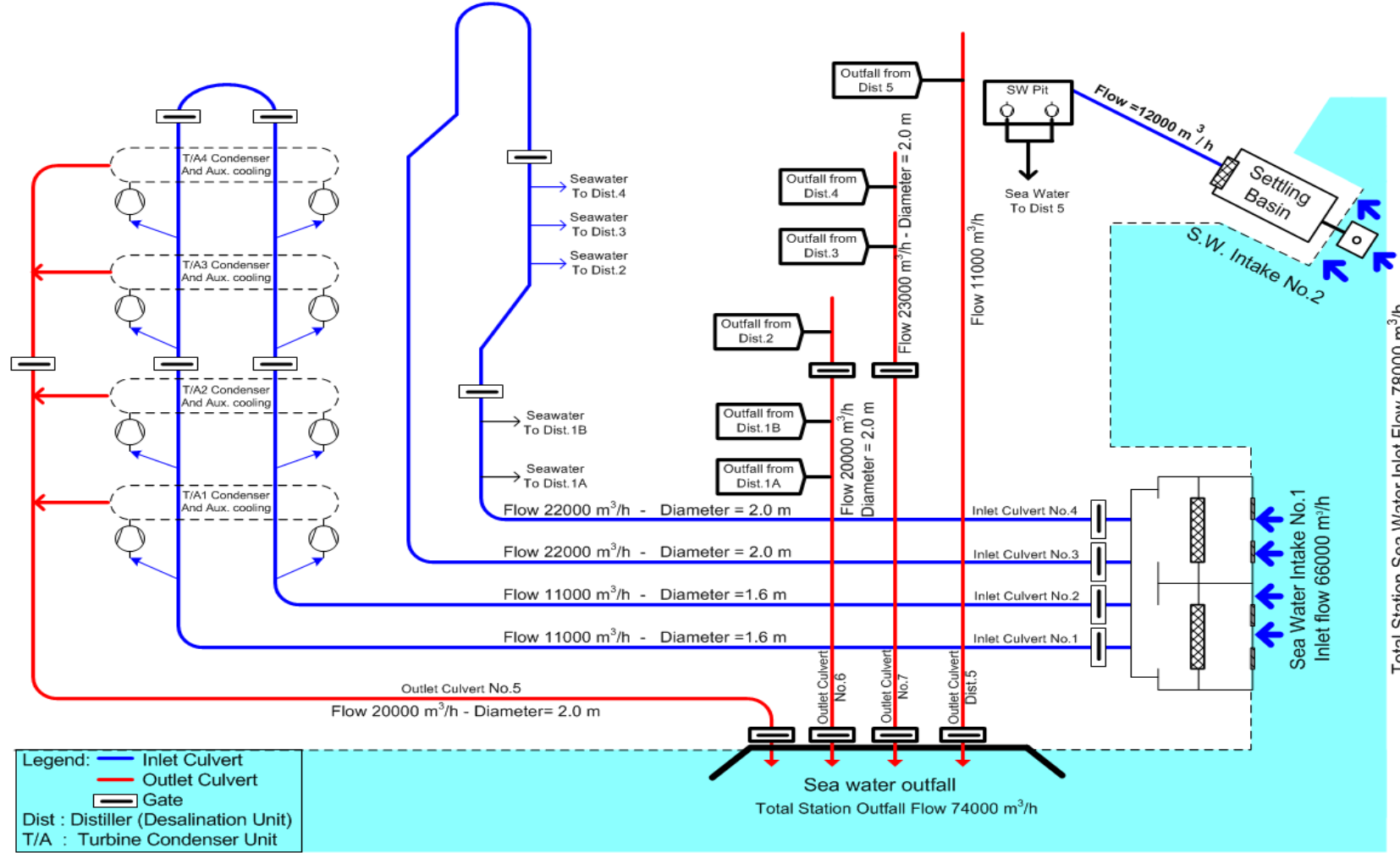

Figure 4. Seawater intake and outfall of SPWS.



Figure 5. Locations of sampling points.

\subsection{Field Survey and Data Acquisition}

The locations of the sampling points are shown in Figure 5. Overall eighteen sampling points were used to characterize the outfall area of SPWS. The locations of the sampling points were determined using a GPS instrument (Garmin). Temperature (in degree centigrade) and salinity (in total dissolved Solids (TDS)) 
were measured at these spot sampling points in the field using Marine Water Quality Monitor (YSI) instrument. The design of the sampling points was made in the form of a grid to ensure full coverage of the spatial distribution of the outfall plume between the two barriers. Sampling points X1 to X16 represent the outfall area, while both points X17 (desalination plant feed-water side) and X18 (outfall side) represent the ambient conditions of the area.

The outfall area and its surrounding are relatively shallow and does not exceed 1.5 meters, with some areas appear at the surface during low tide (Figure 6). Hence, it was felt that it is important to investigate the changes in the salinity and temperature during low and high tides. Sampling and measurements were taken at $25 \mathrm{~cm}$ and $1 \mathrm{~m}$ below the surface of the water column during both high and low tide ( $1.65 \mathrm{~m}$ and $0.96 \mathrm{~m}$, respectively). The sampling for low and high tide was made on the same day (21/02/2013, 08:30 am and 14:42 pm). Table 2 displays the measurement results of the survey during high and low tide at $25 \mathrm{~cm}$ and $1 \mathrm{~m}$ below the surface of water column for the 18 sampling points.

\subsection{Spatial Data Representation}

Data interpolation and contouring was made using the inverse weighted distance

Table 2. Temperature and Total Dissolved Solids Measurements at high tide and low tide at $25 \mathrm{~cm}$ and 1 meter below sea level.

\begin{tabular}{|c|c|c|c|c|c|c|c|c|c|c|}
\hline \multirow{3}{*}{$\begin{array}{l}\text { Sampling } \\
\text { point \# }\end{array}$} & \multirow{2}{*}{\multicolumn{2}{|c|}{ Coordinates }} & \multicolumn{4}{|c|}{ High Tide $(21 / 02 / 2013$ starting at $14: 42 \mathrm{hrs})$} & \multicolumn{4}{|c|}{ Low Tide $(21 / 02 / 2013$ starting at 08:30 hrs) } \\
\hline & & & \multicolumn{2}{|c|}{$\mathrm{T}\left({ }^{\circ} \mathrm{C}\right)$} & \multicolumn{2}{|c|}{ TDS (ppt) } & \multicolumn{2}{|c|}{$\mathrm{T}\left({ }^{\circ} \mathrm{C}\right)$} & \multicolumn{2}{|c|}{ TDS (ppt) } \\
\hline & UTM North & UTM East & $25 \mathrm{~cm}$ & $1 \mathrm{~m}$ & $25 \mathrm{~cm}$ & $1 \mathrm{~m}$ & $25 \mathrm{~cm}$ & $1 \mathrm{~m}$ & $25 \mathrm{~cm}$ & $1 \mathrm{~m}$ \\
\hline 1 & 2896040 & 462557 & 24.61 & 26.80 & 45.34 & 45.93 & 30.64 & 31.01 & 50.55 & 51.25 \\
\hline 2 & 2896023 & 462606 & 25.52 & 29.25 & 45.71 & 47.88 & 26.41 & 31.37 & 47.51 & 51.82 \\
\hline 3 & 2896010 & 462632 & 23.53 & 29.07 & 44.83 & 48.60 & 26.77 & 29.75 & 47.78 & 50.01 \\
\hline 4 & 2895991 & 462689 & 22.66 & 22.86 & 44.26 & 44.89 & 25.51 & 26.88 & 47.28 & 50.06 \\
\hline 5 & 2896015 & 462546 & 29.92 & 30.25 & 45.26 & 50.80 & 31.72 & 36.26 & 47.09 & 56.45 \\
\hline 6 & 2895995 & 462582 & 26.91 & 29.21 & 46.56 & 48.75 & 27.89 & 30.96 & 48.40 & 50.70 \\
\hline 7 & 2895979 & 462636 & 23.21 & 22.87 & 44.51 & 44.53 & 26.41 & 30.69 & 47.21 & 50.56 \\
\hline 8 & 2895962 & 462682 & 21.98 & 25.04 & 44.27 & 45.80 & 25.61 & 31.31 & 47.07 & 50.82 \\
\hline 9 & 2895988 & 462537 & 28.86 & 28.94 & 47.18 & 47.16 & 30.45 & 30.62 & 47.84 & 48.20 \\
\hline 10 & 2895957 & 462589 & 29.01 & 28.88 & 46.91 & 47.06 & 28.84 & 27.97 & 47.36 & 47.38 \\
\hline 11 & 2895926 & 462629 & 29.03 & 29.04 & 46.86 & 46.93 & 29.05 & 28.03 & 47.27 & 47.23 \\
\hline 12 & 2895923 & 462676 & 29.53 & 29.52 & 47.17 & 47.12 & 29.96 & 30.89 & 47.33 & 49.18 \\
\hline 13 & 2895943 & 462529 & 28.95 & 28.99 & 47.20 & 47.15 & 26.73 & 23.50 & 47.61 & 46.65 \\
\hline 14 & 2895912 & 462581 & 28.66 & 28.73 & 47.00 & 47.04 & 26.66 & 26.05 & 47.33 & 47.39 \\
\hline 15 & 2895910 & 462612 & 28.9 & 28.87 & 46.91 & 46.94 & 28.22 & 27.39 & 47.27 & 47.42 \\
\hline 16 & 2895899 & 462674 & 29.01 & 28.90 & 47.04 & 47.22 & 29.49 & 29.81 & 47.60 & 48.19 \\
\hline 17 & 2895917 & 462816 & 20.67 & 21.98 & 43.49 & 43.79 & 26.73 & 26.54 & 47.40 & 47.42 \\
\hline 18 & 2896161 & 462569 & 20.56 & 20.51 & 42.87 & 42.94 & 19.51 & 19.52 & 43.38 & 43.61 \\
\hline
\end{tabular}




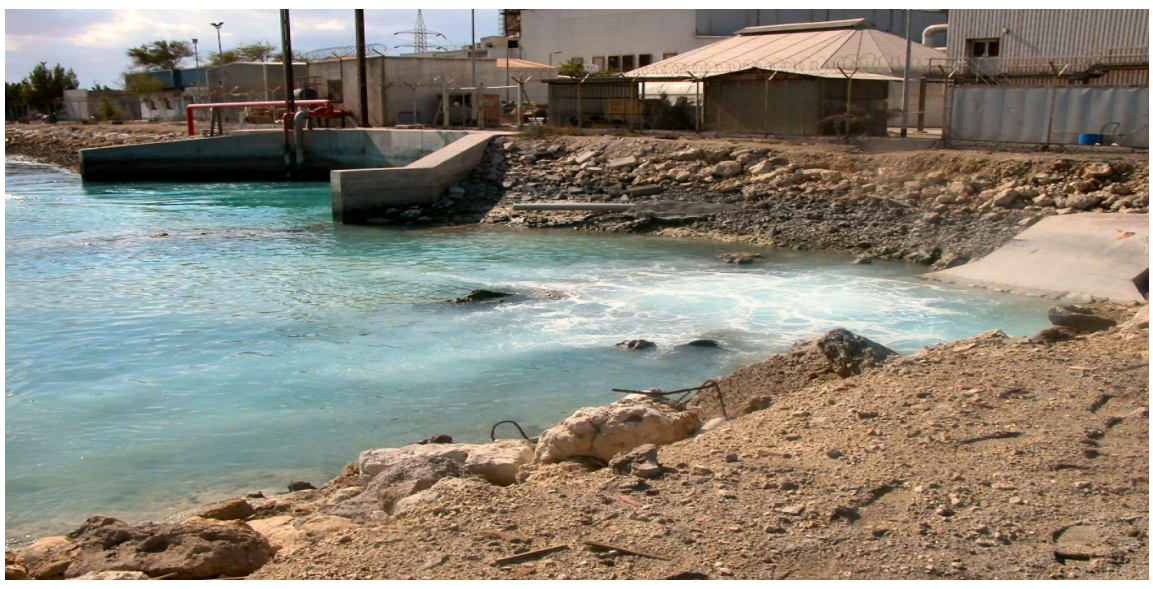

Figure 6. Discharge area of SPWS located at the intertidal zone.

method (power 2) to provide a representative spatial distribution of the salinity and temperature in the field. Surfer (v.8) contouring Software (Golden Software Inc., Golden, Colorado) was used to create the graphical spatial representation of these two variables at $25 \mathrm{~cm}$ and $1 \mathrm{~m}$ below the water surface for both low and high tides. Moreover, the temperature and salinity difference between the $1 \mathrm{~m}$ and the $25 \mathrm{~cm}$ below the surface water column planes for both low and high tides were also prepared by subtracting the produced maps using the same software.

\section{Results and Discussion}

\subsection{Temperature}

The ambient temperature of the study area was $20.5^{\circ} \mathrm{C}$ at high tide and was $19.5^{\circ} \mathrm{C}$ at low tide. The temperature of the brine discharged at the outfall was $37^{\circ} \mathrm{C}$; i.e., the temperature of the brine discharged to the outfall was higher than the ambient temperature by $16.5^{\circ} \mathrm{C}$ at high tide and $17.5^{\circ} \mathrm{C}$ at low tide. (Figure 7 and Figure 8) show the spatial distribution of temperature at $25 \mathrm{~cm}$ and 1 meter below the water surface, respectively, for both high and low tide.

The highest temperature value in the surrounding area of the brine discharge occurred, as expected, very close to the mouth of the outfall; the maximum temperature measured near the outfall point at high tide was $30.3^{\circ} \mathrm{C}$ at $1 \mathrm{~m}$ below surface water column and was $36.3^{\circ} \mathrm{C}$ at low tide. The relatively high increase in temperature at low tide than at high tide is attributed to the extreme reduction of the water column during low tide restricting mixing. The figures indicate that high temperatures are concentrated toward the discharge point at high tide, while at low tide the high temperatures spread toward the open sea. The extent of the mixing zone area was estimated at about $260 \mathrm{~m}$ from the outfall point at high tide, reaching about $1 \mathrm{~km}$ at low tide.

In the vertical direction, temperatures are higher at $1 \mathrm{~m}$ below surface water column than at $25 \mathrm{~cm}$. This is illustrated in Figure 9, which shows the temperature difference between the $1 \mathrm{~m}$ and the $25 \mathrm{~cm}$ below the surface water column 


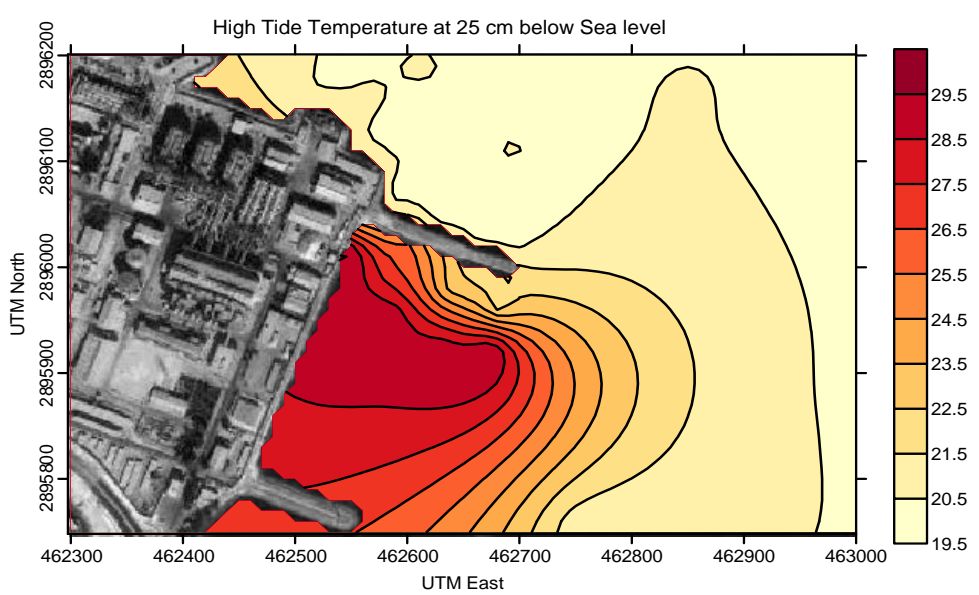

(a)

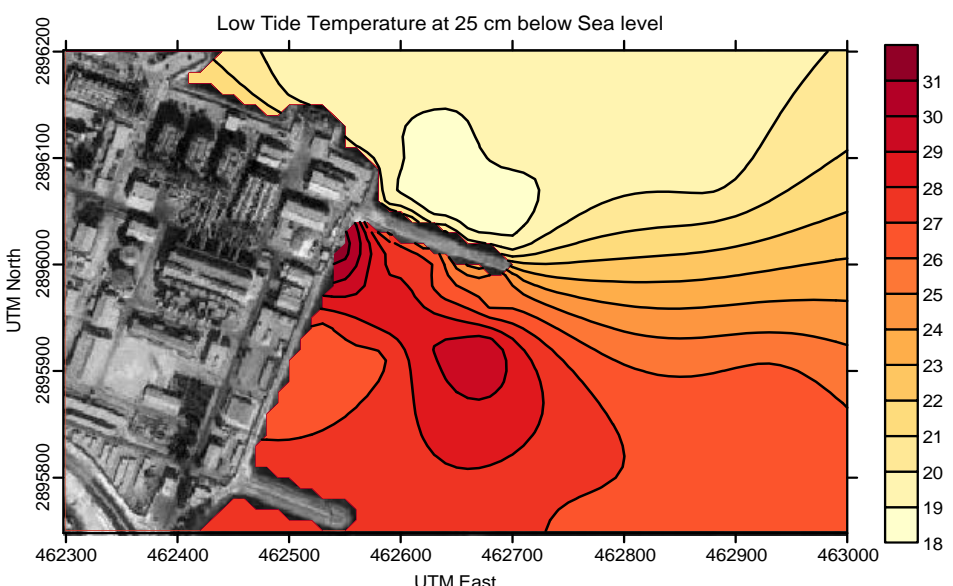

(b)

Figure 7. Observed Temperature at SPWS outfall $25 \mathrm{~cm}$ below sea level, in degrees Centigrade: a) High tide; and b) Low tide.

planes. The maximum difference temperature was $5.5^{\circ} \mathrm{C}$ at low tide and $5^{\circ}$ at high tide.

The measured temperatures were compared with mixing zone water quality standards of the Kingdom of Bahrain, which states that there should be no direct heat addition within $100 \mathrm{~m}$ of shoreline and no thermal alteration, which would cause temperature to deviate from ambient temperature by more than $3^{\circ} \mathrm{C}$ (Environmental Legislative Decree 21 for the year 1996). The survey results showed that brine thermal discharge is not in compliance with the standard limits at high tide and low tide (refer to samples 1, 2, 5, and 6 in Table 2). At low tide, the difference reached more than $10^{\circ} \mathrm{C}$. It is observed that the impact of the temperature of the brine discharge at low tide is generally more than that at high tide. This is attributed to the relatively shallow area of the discharge zone, where mixing becomes even more restricted at low tide.

\subsection{Salinity}

The average ambient salinity at high tide and low tide was $43.2 \mathrm{ppt}$. The brine 


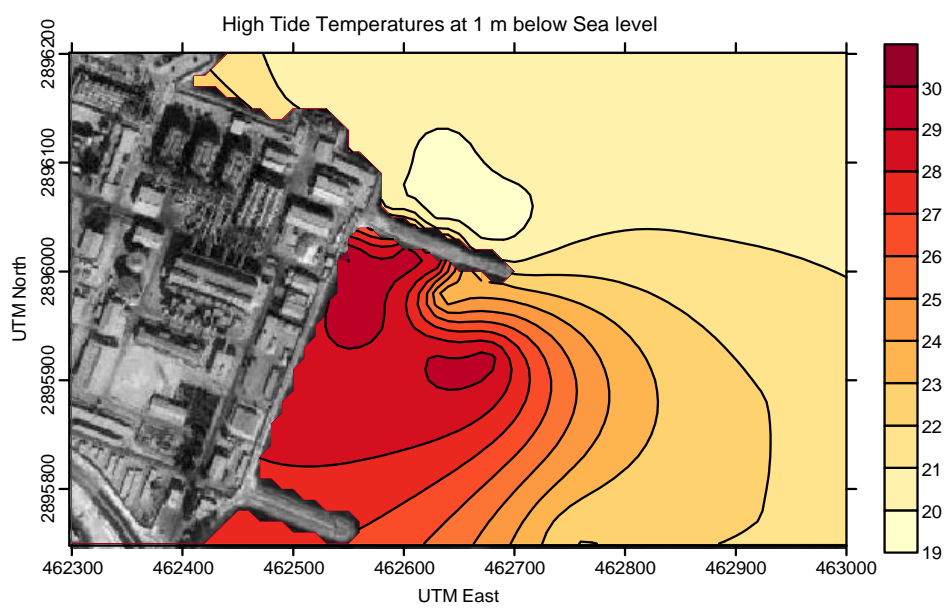

(a)

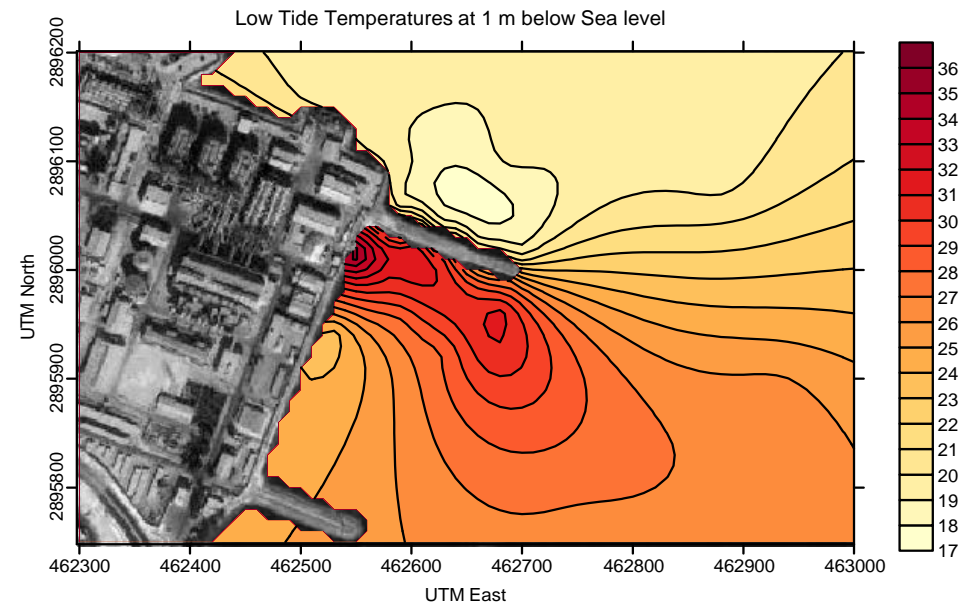

(b)

Figure 8. Observed Temperature at SPWS outfall $1 \mathrm{~m}$ below sea level, in degrees centigrade: a) High tide; and b) low tide.

salinity discharged at the outfall was $56 \mathrm{ppt}$; i.e., the salinity of the brine discharged to the outfall was higher than the ambient salinity by $13 \mathrm{ppt}$. Figure 10 and Figure 11 show the spatial distribution of TDS at high and low tide for 25 $\mathrm{cm}$ and $1 \mathrm{~m}$ sampling depths, respectively. The highest TDS value in the surrounding area of the brine discharge occurred very close to the mouth of the outfall, with the maximum salinity measured near the outfall point was $56 \mathrm{ppt}$ at low tide and $51 \mathrm{ppt}$ at high tide, both at $1 \mathrm{~m}$ below the surface water column. The relatively high increase in the salinity at low tide than at high tide is attributed to the shallow areas of the outfall at during low tide which leads to less mixing and dilution of the brine. The two figures indicate that, as was the case of the temperature, at high tide, the salinity plume is concentrated within the discharge area, while at low tide the salinity plume is spread towards the open sea.

Vertically, the two figures indicate that the salinity of the seawater is higher at $1 \mathrm{~m}$ below surface water column than at $25 \mathrm{~cm}$. This can be clearly observed in Figure 12, which shows the salinity difference between $1 \mathrm{~m}$ and $25 \mathrm{~cm}$ below the 


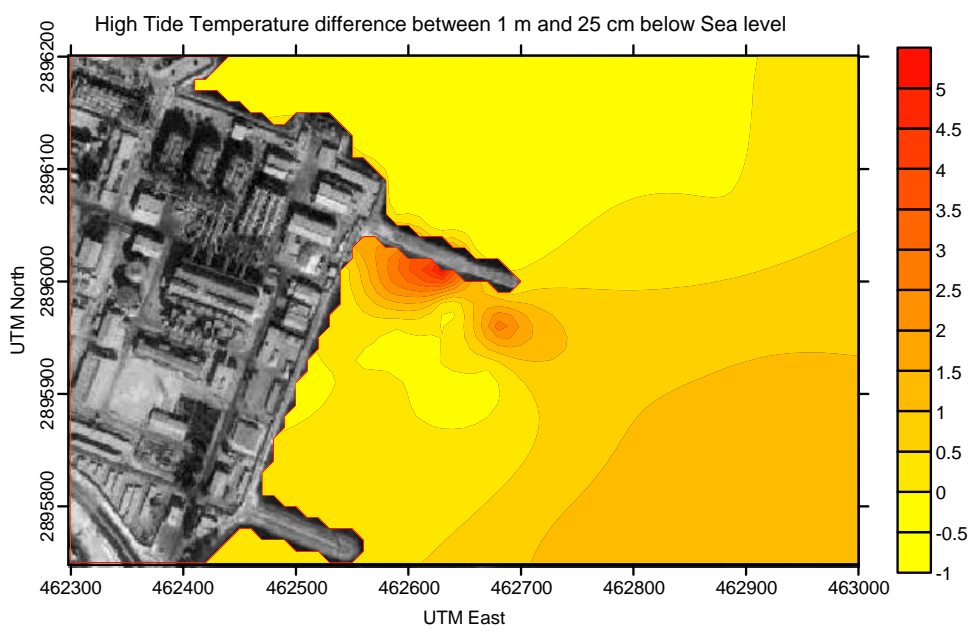

(a)

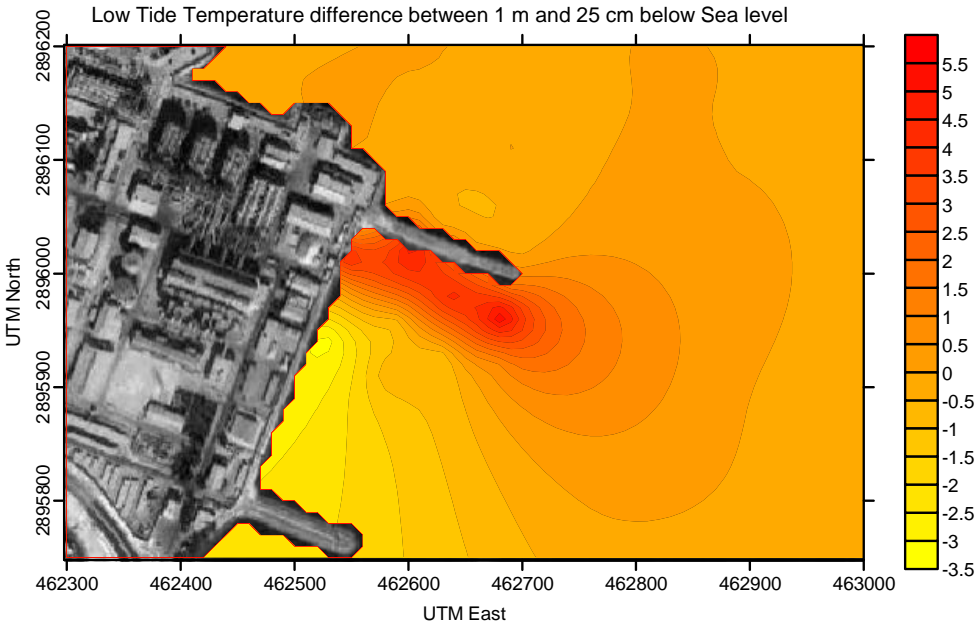

(b)

Figure 9. Observed Temperature Difference at SPWS outfall between $1 \mathrm{~m} \&$ $25 \mathrm{~cm}$ below sea level, in degrees centigrade a) High tide; and b) Low tide.

surface water column. The maximum difference in salinity at low tide was 7.5 ppt and it was $4.4 \mathrm{ppt}$ at high tide. This difference in salinity at different level is attributed to the brine density is higher than seawater density leading it to sink toward the sea bed.

Bahrain has no regulation for the salinity at the outfall area (i.e., Environmental Legislative Decree 21 for the year 1996), and compliance analysis cannot be made. However, if compared with the standards of other Gulf countries, for example the Emirate of Dubai, where the standard is set to have the salinity not to exceed $5 \%$ of the ambient seawater salinity within $100 \mathrm{~m}$ from the outfall area, then this criteria has been exceeded at all times.

\section{Conclusions and Recommendations}

The outfall area of the MSF desalination plant of Sitra Power and Water Station was characterized in terms of the spatial distribution of the brine salinity and 


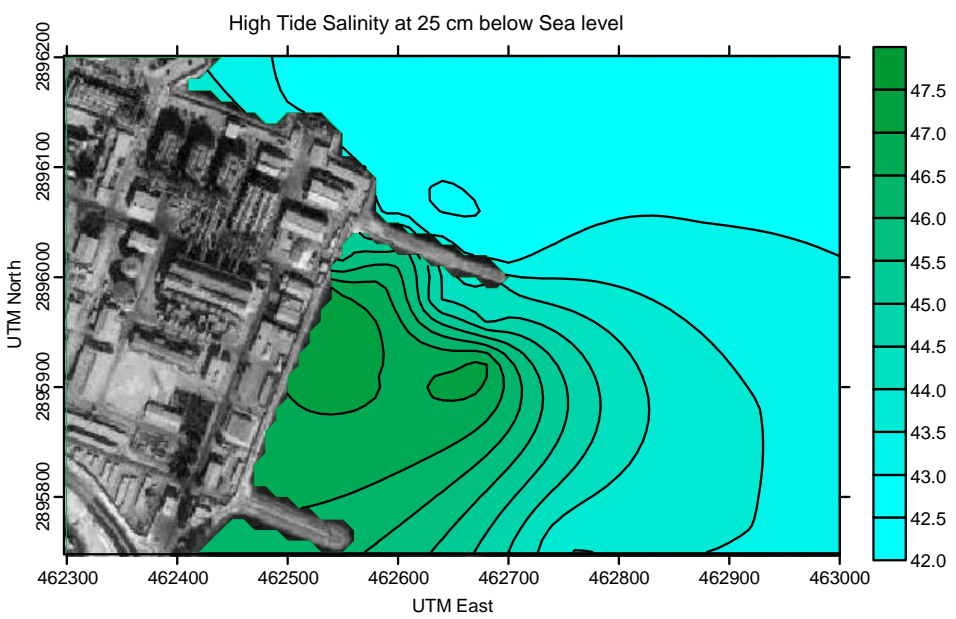

(a)

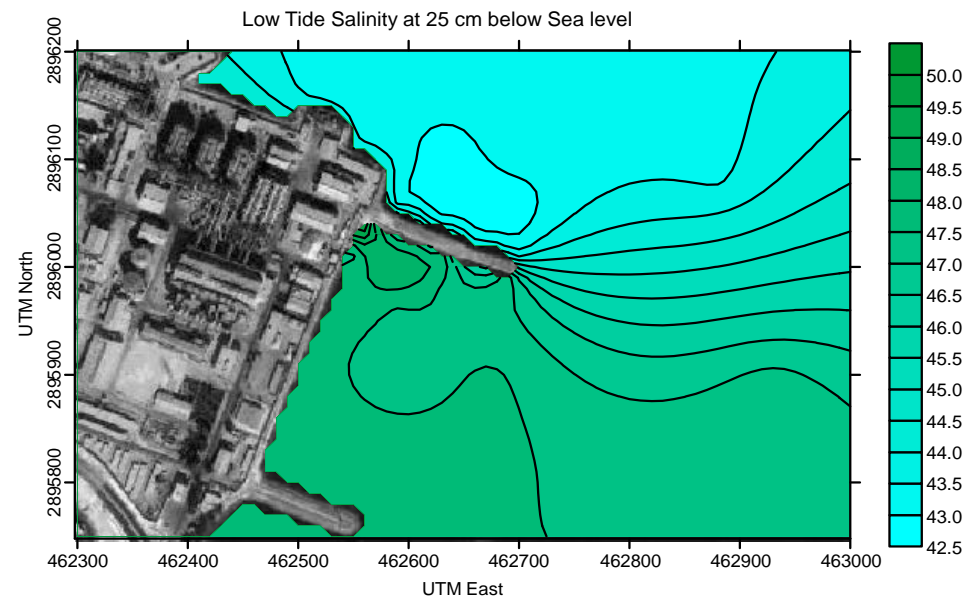

(b)

Figure 10. Observed TDS at SPWS outfall $25 \mathrm{~cm}$ below sea level, in ppt: a) High tide; and b) Low tide.

temperature. The survey results have clearly shown that the current design structure consisting of two jetties to isolate the desalination plant outfall area from its surroundings is not environmentally sound, and is actually contributing to increasing the concentration of the salinity and temperature within the surrounding zone, and making these two parameters exceed the discharge standards.

The current design of the outfall area needs to be reviewed to ensure meeting brine discharge regulations and mitigate its impact on the surrounding marine area. In order to do so, optimized high efficiency mixing designs are needed for the brine discharge as part of a sustainable concentrate management plan. The current surface/inter-tidal location is susceptible to significant increases in salinity and temperature around the outfall area due to the limited flushing it experiences. The spatial extent of the brine plume can be minimized by building a discharge area further offshore at a sub-tidal location where turbulent flow exists to minimize the spatial extent and intensity of the brine plume. 


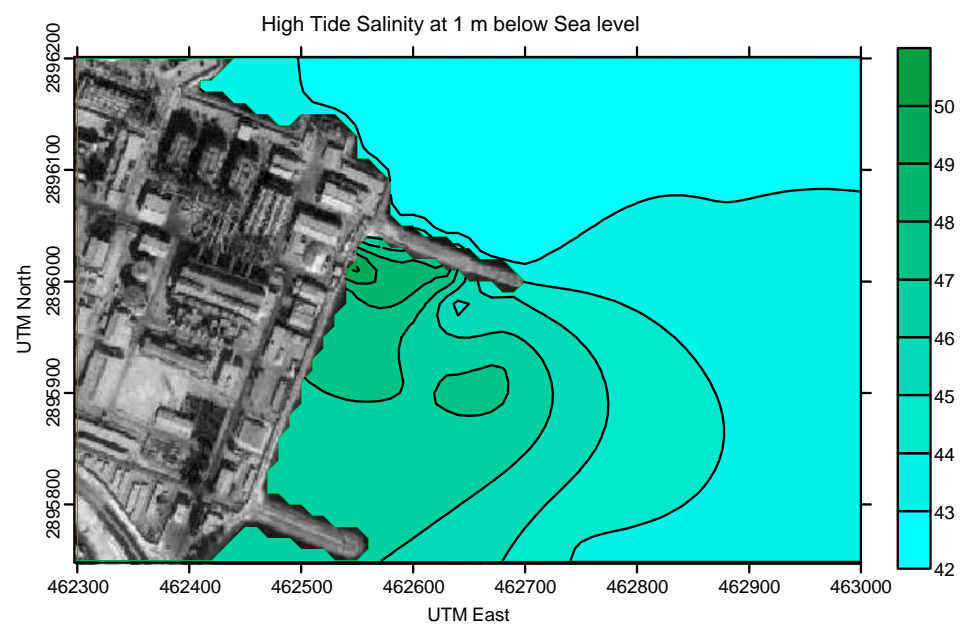

(a)

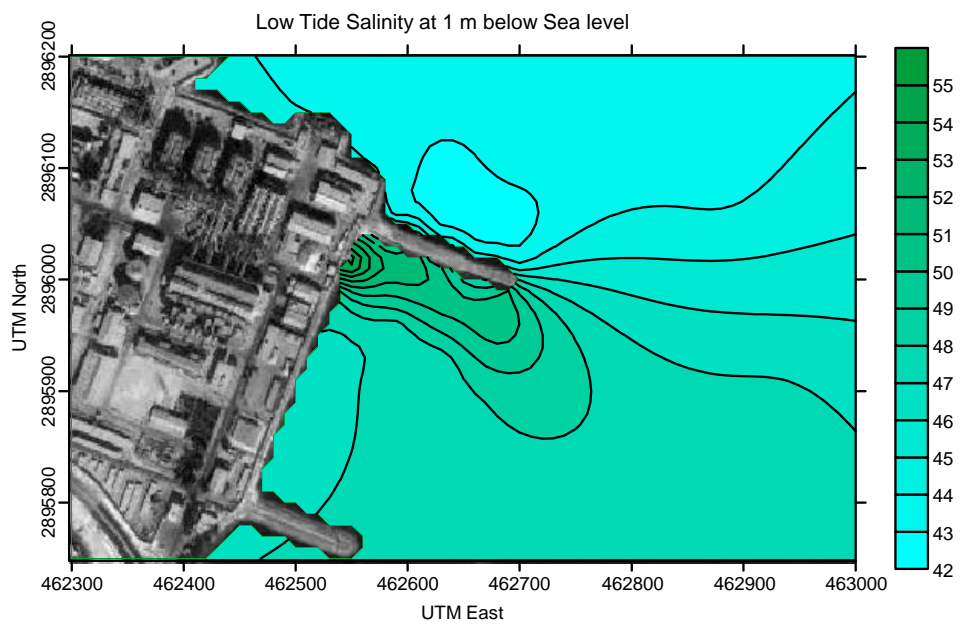

(b)

Figure 11. Observed TDS at SPWS outfall $1 \mathrm{~m}$ below sea level, in ppt: a) High tide; and b) Low tide.

In this research, two indicators, temperature and salinity, were used to characterize and assess the physical changes of the seawater surrounding the outfall area of the Sitra desalination plant. However, it is recommended that other quantifiable indicators characterize the desalination system impact on the marine environment and hence help in the assessment process, such as chemicals used in process and residual chlorine in order to enhance the impact assessment process.

In addition, this field survey was conducted during the winter season, where major differences in temperature occur. It is recommended that a continuous monitoring program of seawater quality, including selected sustainability indicators be designed and implemented to measure these indicators on a regular basis (e.g., monthly or quarterly) in the near field region (NFR) and the regulatory mixing zone (RMZ) to aid in the observation of the outfall region and its modeling. Moreover, such a regular monitoring program is to be complemented 


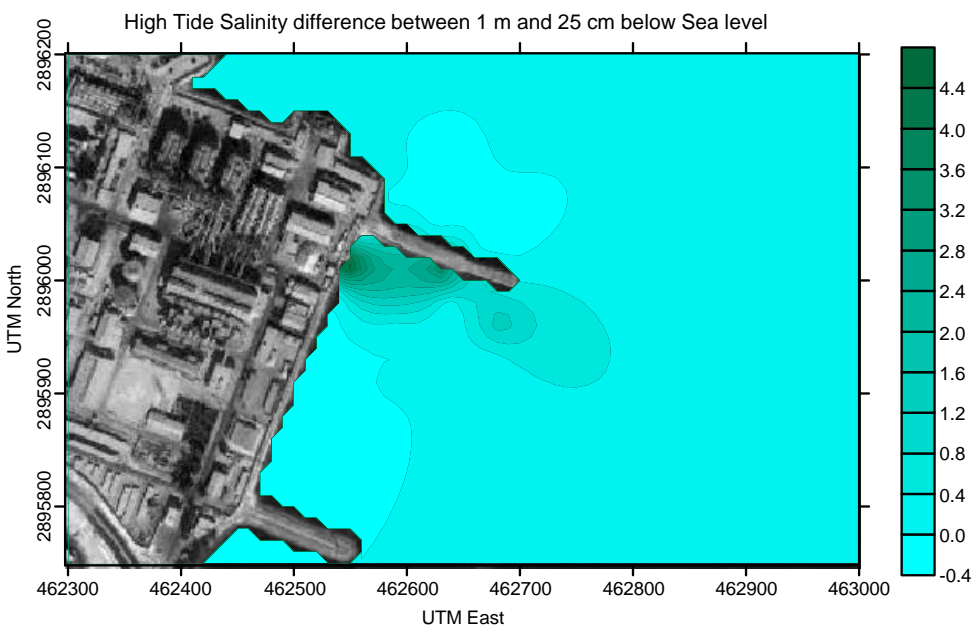

(a)

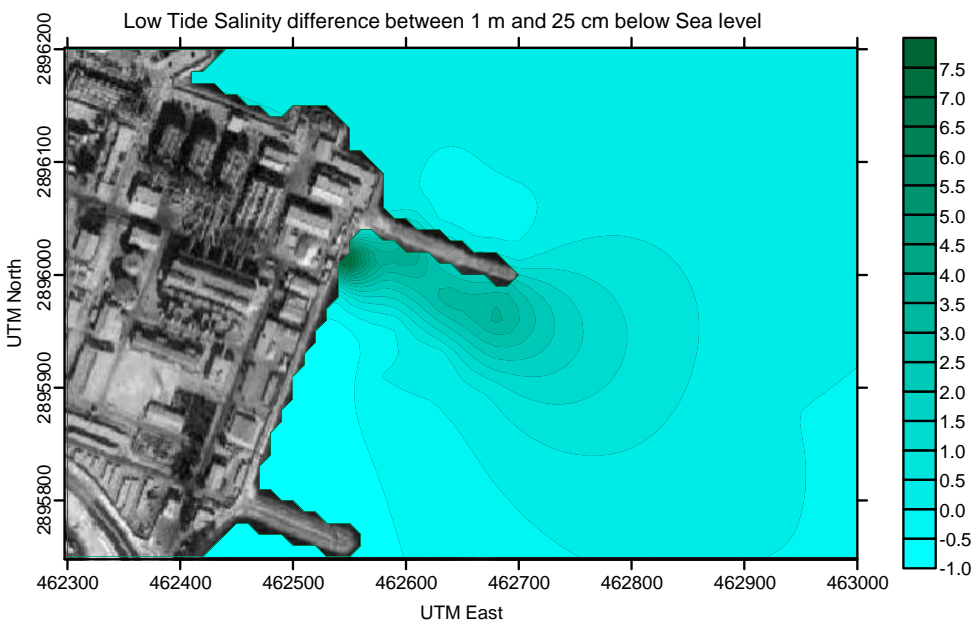

(b)

Figure 12. Observed TDS Difference at SPWS outfall between $1 \mathrm{~m} \& 25 \mathrm{~cm}$ below sea level, in ppt: a) High tide; and b) Low tide.

by monitoring of selected biological communities and organisms of ecological relevance and sensitivity to salinity and temperature. Such characterization and impact assessment are recommended to be extended to all desalination plants in Bahrain.

Finally, it is recommended that the results of this characterization are used in the development of a hydrodynamic simulation model (e.g., CORMIX) representing the desalination plant and its surrounding environment, and are used to investigate the effectiveness of various proposed mitigation options to minimize the impact of the outfall area on the marine environment.

\section{Acknowledgments}

Special thanks to Mr. Hassan Juma, Head, Laboratories, Supreme Council for Environment, Kingdom of Bahrain, for his help in collecting and analyzing the marine samples. 


\section{References}

[1] Falkenmark, M. (1989) The Massive Water Scarcity Now Threatening Africa-Why Isn't It Being Addressed. Ambio, 18, 112-118.

http://www.researchgate.net/publication/279599915_The_Massive_Water_Scarcity_ Now_Threatening_Africa-Why_Isn't_It_Being_Addressed

[2] Al-Jamal, K. and Schiffler, M. (2009) Desalination Opportunities and Challenges in the Middle East and North Africa Region. In: Jagannathan, N.V., Mohamed, A.S. and Kremer, A., Eds., Water in the Arab World: Management Perspectives and Innovations, World Bank, Washington, DC.

http://siteresources.worldbank.org/INTMENA/Resources/Water_Arab_World_full. pdf

[3] Al-Zubari, W.K. (2014) The Costs of Municipal Water Supply in Bahrain. Energy, Environment and Resources (Produced as Part of the Valuing Vital Resources in the Gulf Series), Chatham House, UK.

http://www.chathamhouse.org/sites/files/chathamhouse/field/field_document/2014 1216MunicipalWaterBahrainAlZubari.pdf

[4] Höpner, T. and Windelberg, J. (1996) Elements of Environmental Impact Studies on Coastal Desalination Plants. Desalination, 108, 11-18.

http://www.sciencedirect.com/science/article/pii/S0011916497000039 https://doi.org/10.1016/S0011-9164(97)00003-9

[5] El-Sadek, A. (2010) Water Desalination: An Imperative Measure for Water Security in Egypt. Desalination, 250, 876-884.

http://www.sciencedirect.com/science/article/pii/S0011916409011825 https://doi.org/10.1016/j.desal.2009.09.143

[6] Areiqat, A. and Mohamed, K. (2005) Optimization of the Negative Impact of Power and Desalination Plants on the Ecosystem. Desalination, 185, 95-103. http://www.sciencedirect.com/science/article/pii/S0011916405006120 https://doi.org/10.1016/j.desal.2005.04.038

[7] Lattemann, S. and Hopner, T. (2008) Environmental Impact and Impact Assessment of Seawater Desalination. Desalination, 220, 1-15.

http://www.sciencedirect.com/science/article/pii/S0011916407006005 https://doi.org/10.1016/j.desal.2007.03.009

[8] Danoun, R. (2007) Desalination Plants Potential Impacts of Brine Discharge on Marine Life. The University of Sydney, Australia.

[9] Bleninger, T. and Jirka, G. (2008) Modelling and Environmentally Sound Management of Brine Discharges from Desalination Plants. Desalination, 221, 585-597.

http://www.sciencedirect.com/science/article/pii/S0011916407007448 https://doi.org/10.1016/j.desal.2007.02.059

[10] Einav, R. and Lokiec, F. (2003) Environmental Aspects of a Desalination Plant in Ashkelon. Desalination, 156, 79-85.

http://www.sciencedirect.com/science/article/pii/S001191640300328X https://doi.org/10.1016/S0011-9164(03)00328-X

[11] Baalousha, H. (2006) Desalination Status in the Gaza Strip and Its Environmental Impact. Desalination, 196, 1-12.

http://www.sciencedirect.com/science/article/pii/S0011916406004176 https://doi.org/10.1016/j.desal.2005.12.009

[12] Malfeito, J., Díaz-Caneja, J., Fariñas, M., Fernández-Torrequemada, Y., GonzálezCorrea, J., Carratalá-Giménez, A. and Sánchez-Lizaso, J. (2005) Brine Discharge from the Javea Desalination Plant. Desalination, 185, 87-94. 
http://www.sciencedirect.com/science/article/pii/S0011916405006119 https://doi.org/10.1016/j.desal.2005.05.010

[13] Ketsetzi, A., Stathoulopoulou, A. and Demadis, K. (2008) Being Green in Chemical Water Treatment Technologies: Issues, Challenges and Development. Desalination, 223, 487-493. http://www.sciencedirect.com/science/article/pii/S0011916408000854 https://doi.org/10.1016/j.desal.2007.01.230

[14] Mavredaki, E., Stathoulopoulou, A., Neofotistou, E. and Demadis, K. (2007) Environmentally Benign Chemical Additives in the Treatment and Chemical Cleaning of Process Water Systems: Implications for Green Chemical Technology. Desalination, 210, 257-265. https://doi.org/10.1016/j.desal.2006.05.050 http://www.sciencedirect.com/science/article/pii/S0011916407001865

[15] Al-Barwani, H. and Purnama, A. (2007) Re-Assessing the Impact of Desalination Plants Brine Discharges on Eroding Beaches. Desalination, 204, 94-101. http://www.sciencedirect.com/science/article/pii/S0011916406013105 https://doi.org/10.1016/j.desal.2006.03.536

[16] Al-Barwani, H. and Purnama, A. (2008) Simulating Brine Plumes Discharged into the Seawaters. Desalination, 221, 608-613.

http://www.ifh.uni-karlsruhe.de/science/envflu/research/brinedis/publications/2212008-608-813.pdf https://doi.org/10.1016/j.desal.2007.02.060

[17] Purnama, A., Al-Barwani, H. and Al-Lawatia, I. (2003) Modelling Dispersion of Brine Waste Discharges from a Coastal Desalination Plant. Desalination, 155, 41-47. http://www.sciencedirect.com/science/article/pii/S0011916403002376 https://doi.org/10.1016/S0011-9164(03)00237-6

[18] Shao, D. and Law, A. (2009) Salinity Build-Up Due to Brine Discharges into Shallow Coastal Waters. Modern Physics Letters B, 23, 541-544. http://www.worldscientific.com/doi/abs/10.1142/S0217984909018850 https://doi.org/10.1142/S0217984909018850

[19] Altayaran, A. and Madany, I. (1992) Impact of a Desalination Plant on the Physical and Chemical Properties of Seawater. Bahrain. Water Research, 26, 435-441. http://www.researchgate.net/publication/248328202_Impact_of_a_desalination_pla nt_on_the_physical_and_chemical_properties_of_seawater_Bahrain https://doi.org/10.1016/0043-1354(92)90043-4 